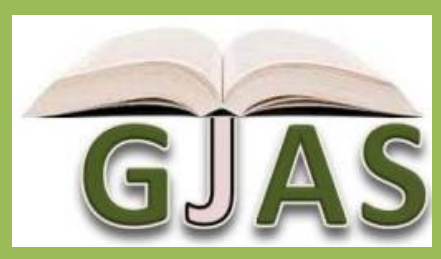

\title{
Effects of Aloe Vera Coatings on Quality Characteristics of Oranges Stored Under Cold Storage
}

\section{${ }^{*}$ Arowora K.A. ${ }^{1}$, Williams J.O ${ }^{1}$, Adetunji C.O. ${ }^{1}$, Fawole O.B. ${ }^{2}$, Afolayan S.S. ${ }^{1}$, Olaleye O.O. ${ }^{1}$, Adetunji J.B. ${ }^{3}$ and Ogundele B.A. ${ }^{1}$}

Nigerian Stored Products Research Institute, Km 3, Asa dam road, P.M.B. 1489, Ilorin, Kwara state.

University of llorin, Department of Agronomy, Department of Biochemistry P.M.B. 1515, llorin, Kwara state

Article No.: 110112192

DOI: 10.15580/GJAS.2013.1.110112192

Submitted: 01/11/2012

Accepted: 15/11/2012

Published: 20/01/2013

*Corresponding Author

Arowora, K.A.

E-mail: arowora

2001@yahoo.com

Keywords:

Coatings, Aloe vera, quality,

oranges, storage
Three hundred and twenty (320) oranges of Valencia variety were stored under cold conditions in the refrigerator for 8 weeks. The following parameters were carried out during the course of storage: Total soluble solids, titratable acidity, weight loss, firmness, $\mathrm{pH}$, vitamin $\mathrm{C}$ and sugar/ acid ratio. The final value for firmness for coated oranges was found to be $1781.25+118.30 \mathrm{~N}$, while that of uncoated oranges was $1531.25 \pm 185.53 \mathrm{~N}$. The $\mathrm{pH}$ was gradually increasing during the course of storage in the two treatments, whereas vitamin $\mathrm{C}$ was found to be decreasing in storage. The total soluble solid for coated oranges was $9.79+1.14 \%$ while that of uncoated oranges was found to be $9.34 \pm 0.06 \%$ at the end of storage. There was a linear decrease in titratable acidity during the course of storage. It was found that the value obtained for coated oranges was higher than that of uncoated oranges which was obtained to be $1.14 \pm 0.07$ at the end of storage. Converse to this was obtained for \% weight losses in the two treatments. The weight loss for coated oranges was $29.20 \pm 0.55 \%$, while that of uncoated oranges was $53.30 \pm 1.17 \%$ at the end of storage. A linear increase was observed in sugar/acid ratio in the two treatments during the course of storage with higher value being recorded for uncoated oranges as $8.90 \pm 0.87$, while lower value was gotten for coated oranges as $7.43 \pm$ $0.34 \%$. 


\section{INTRODUCTION AND LITERATURE REVIEW}

The importance of good postharvest practices in minimizing postharvest losses cannot be overemphasized. Appropriate preharvest, harvesting and postharvest chain will result in superior quality produce. The sweet orange (Citrus cinensis) is the most commonly grown fruit tree in the whole world ( Morton,1987). It is made up of soft texture, and the edible materials are very important in human diet since they contain essential vitamins.

Edible surface coatings such as waxes are often applied to improve the cosmetic features of fruits and vegetables. These coatings commonly contain ingredients such as polyethylene, carnauba or candelilla, all of which reduce water vapour loss and provide a vehicle for fungicides (Hagenmaier and Baker, 1995; Debeaufort et al., 1998; Alleyne and Hagenmaier, 2000). Several authors including Amarante et al. (2001); Jeong et al., (2003) have reported that waxing and coating improves shelf life, slows down ripening, retards water loss, reduces decay and enhances visual quality. It has been estimated that $25 \%$ to $80 \%$ of harvested fresh fruits are lost due to spoilage (Quezada et al., 2003).

Aloe vera is a tropical and subtropical plant that has been used for centuries for its medicinal and therapeutic properties (Eshun et al., 2004). The two major liquid sources of $A$. vera are a yellow latex (exudates) and a clear gel (mucilage), which proceeds from the large leaf parenchymatic cells (Ni et al., 2004). The predominant medical uses of the orally ingested gel juice are against ulcerous, gastrointestinal, kidney and cardiovascular problems and also reduces the cholesterol and triglyceride levels in blood. Moreover, other properties such as anti-inflammatory and antibiotic activities against some diseases (diabetics, cancer, allergy, AIDS) have been reported (Eshun et al., 2004; Reyhlds et al., 1999). Although the main use of $A$. vera gel is in the cosmetic industry, including treatment of burns and scars and in wound healing (Aburjai et al., 2004). There are some reports on the antifungal activity of A. vera gel against several pathogenic fungi including Botrytis cinerea (Jasso de Rodriguez et al., 2005; saks and Barkai-Golan, 1995).

There has been increasing interest in the use of A. vera gel in the food industry as a functional ingredient (Moore et al., 2005). Nevertheless, most of the so- called aloe vera products may contain very small amounts of the

active compounds, because the processing techniques used to obtain A. vera gel affects the product quality and the amount of bioactive compounds in the final product.

It has been found that a procedure of extraction and processing has been developed to ensure the biological integrity, sensorial stability and the quality of the final product for the food industry application ( $\mathrm{He}$ et al., 2005). Aloe vera based edible coatings have been shown to prevent loss of moisture and firmness, control respiration rate and maturation development, delay oxidative browning, and reduce microorganism proliferation in fruits such as sweet cherry, table grapes and recterones (Valverde et al., 2005; Matinez-Romero et al., 2005; Ahmed et al., 2009). In addition to the traditional role of edible coatings as a barrier to water loss and delaying fruit senescence, the new generation coatings are being designed for incorporation and/or for controlled release of antioxidants, nutraceuticals, chemical additives and natural antimicrobial agents (Vargas et al., 2008). It has also been reported that the Aloe vera extracts possessed antimicrobial activity against bacterial pathogens from gram positive and gram negative (Adetunji, 2008).

In view of the fact that there are no recent report on the utilization of Aloe vera in extending the shelf-life of oranges, therefore this study was conducted to fill the gap by evaluating the effects of Aloe vera gel coatings on quality and storability of orange fruit.

\section{MATERIALS AND METHODS}

\section{Preparation of edible coatings of Aloe vera}

Matured leaves of Aloe vera plants were harvested and washed with a mild $25 \%$ chlorine solution. Aloe vera matrix was then separated from the outer cortex of leaves and this colourless hydroparenchyma was ground in a blender. The resulting mixture was filtered to remove the fibres. The liquid obtained constituted fresh Aloe vera gel. The gel matrix was pasteurized at $70^{\circ} \mathrm{C}$ for 45minutes and allowed to cool immediately to an ambient temperature. Ascorbic acid $(2.0 \mathrm{gl})$ and then citric acid $(4.5 \mathrm{gV})$ were added to maintain its $\mathrm{pH}$ at 4 . The viscosity of Aloe vera and its coating efficiency was improved by using $1 \%$ commercial gelling agent which was used as coating agent. This was later stored in brown amber bottle to prevent oxidation of gel using the method (He et al., 2005).

\section{Procurement of Samples}

Freshly harvested valencia oranges were procured from a local market in llorin, kwara state, Nigeria. Mature green wholesome oranges were selected for this study. Fresh leaves of Aloe vera were obtained from the garden of Nigerian Stored Products Research Institute in llorin.

\section{Surface Preparation of oranges}

The primary purpose of surface preparation was to remove all contaminants that would hinder proper coating adhesion and to render a sound, clean substrate, suitable for firm bonding. The surface should be in plant ready condition.

\section{Treatments}


The experiment was a completely randomized design. Three hundred and twenty (320) wholesome oranges were randomly selected into two main groups, one group (160 oranges) was coated with Aloe vera, while another group of 160 oranges was not coated i.e. control. Twenty oranges each were arranged in small plastic baskets. The baskets containing the oranges were stored at refrigerated temperature $\left(12^{\circ} \mathrm{C}, \quad 96-98 \% \mathrm{RH}\right)$. Physicochemical parameters were carried out weekly in triplicates.

\section{Physicochemical Analysis}

Total soluble solids (TSS) were determined using the method of Dong et al. (2001). Individual orange fruit from each treatment was ground in an electric fruit juice extractor to obtain freshly prepared juice soluble solids. This was measured using portable refractometer in brix $\%$.

The titrable acidity was determined by the standard method of the Association of Official Analytical Chemists (2000), by titrating $10 \mathrm{ml}$ of the juice of orange sample and two drops of phenolphthalein indicator with $0.1 \mathrm{~N} \mathrm{NaOH}$ to the pink end point colouration.

Weight changes /weight losses were determined using analytical weighing balance. Firmness was measured as the maximum penetration force $(\mathrm{N})$ reached during tissue breakeage and determined with a $5 \mathrm{~mm}$ diameter flat probe. The penetration depth was $5 \mathrm{~mm}$ and a cross-head speed was $5 \mathrm{~mm} \mathrm{~S}^{-1}$ using TAXT2 Texture analyzer (Stable Micro Systems, Godalming, UK).

For $\mathrm{pH}$ determination, samples were cut into small pieces and homogenized in a grinder, $10 \mathrm{ml}$ of ground orange juice was suspended in $100 \mathrm{ml}$ of distilled water and then filtered. The $\mathrm{pH}$ of the sample was determined using a $\mathrm{pH}$ meter $(\mathrm{pH}-526$, WTW measurement systems). Vitamin $\mathrm{C}$ content of the samples was measured using 2, 6-dichlorophenol indophenol method as described by (A.O.A.C., 2000). The sugar/acid ratio of the samples was determined by dividing sugar concentration (brix) by the citric acid concentration.

\section{RESULTS AND DISCUSSION}

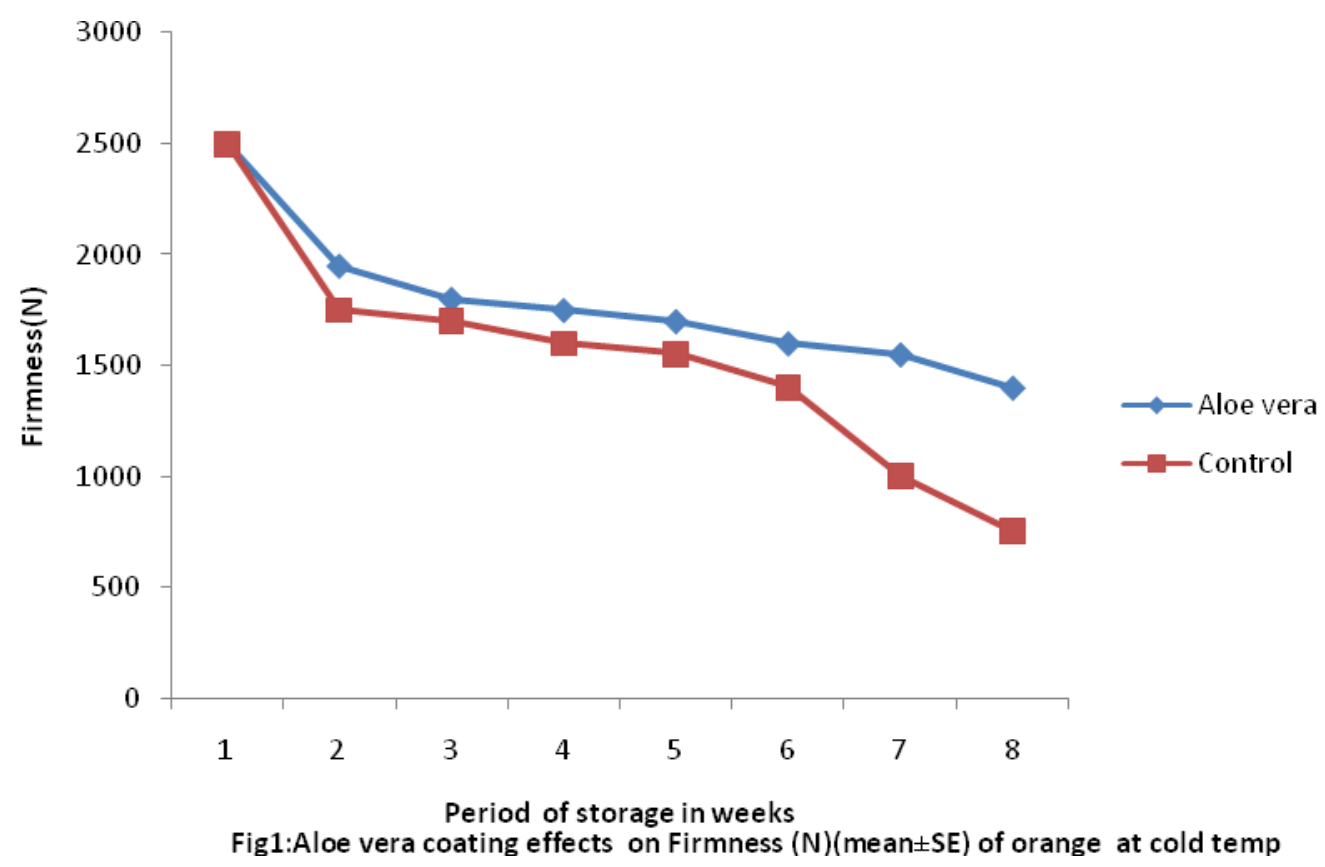

Figure 1 shows the effects of coating on firmness. There was a decreasing trend in firmness in both coated and uncoated oranges during the course of storage. However, the control (untreated fruits) exhibited higher loss in firmness than the coated samples; this was due to the effects of waxing which delayed softening in coated samples. This is in agreement with the observation by Hagenmaeir and Baker (1995) who found that coating with wax reduces shriveling of oranges than the control. The retention of firmness in coated fruits was due to reduction in degradation of insoluble protopectins to more soluble pectic acid and pectin. It was found that during fruit ripening, depolymerization or shortening of chain length of pectin substances occurs with an increase in pectineesterase and polygalacturonase activities (Yaman and Bayoindirli, 
2002). Hence low oxygen and high carbon-dioxide concentrations reduce the activities of these enzymes and allows retention of the firmness during storage (Salunkhe et al., 1991). It was found that the mean value for the firmness of coated oranges was $1781.25 \pm$ $118.30 \mathrm{~N}$ while that of the uncoated oranges was $1531.25 \pm 185 \mathrm{~N}$. Hence, our results are in agreement with the findings by Yaman and Bayoindirli (2002), who worked on cherries coated with semperfresh. Also, the results of this work is in line with that of Patricia et al.,(2005) who reported that refrigerated strawberry coated with wheat gluten-based films had better firmness retention than control fruit.

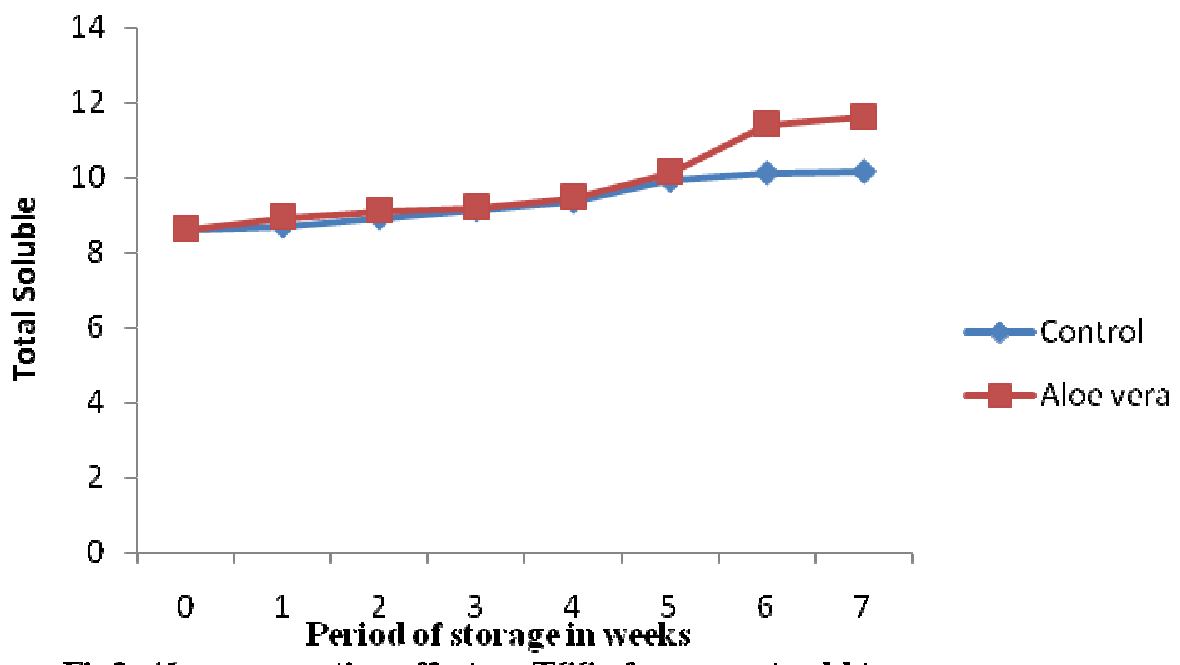

Fig2:-4loe vera coating effect on TSS of orange at cold temp

Figure 2 shows that the mean value for TSS of coated oranges was $9.79 \pm 0.40 \%$, while that of uncoated oranges was $9.34 \pm 0.02 \%$. There was no significant difference $(P>0.0 .05)$ in these values. These results were in accord with that of Kittur et al. (2001) who worked on banana and mango coated with polysaccharide-based coatings and that of Patricia et al. (2005) who worked on strawberry coated with wheat gluten-based

films.

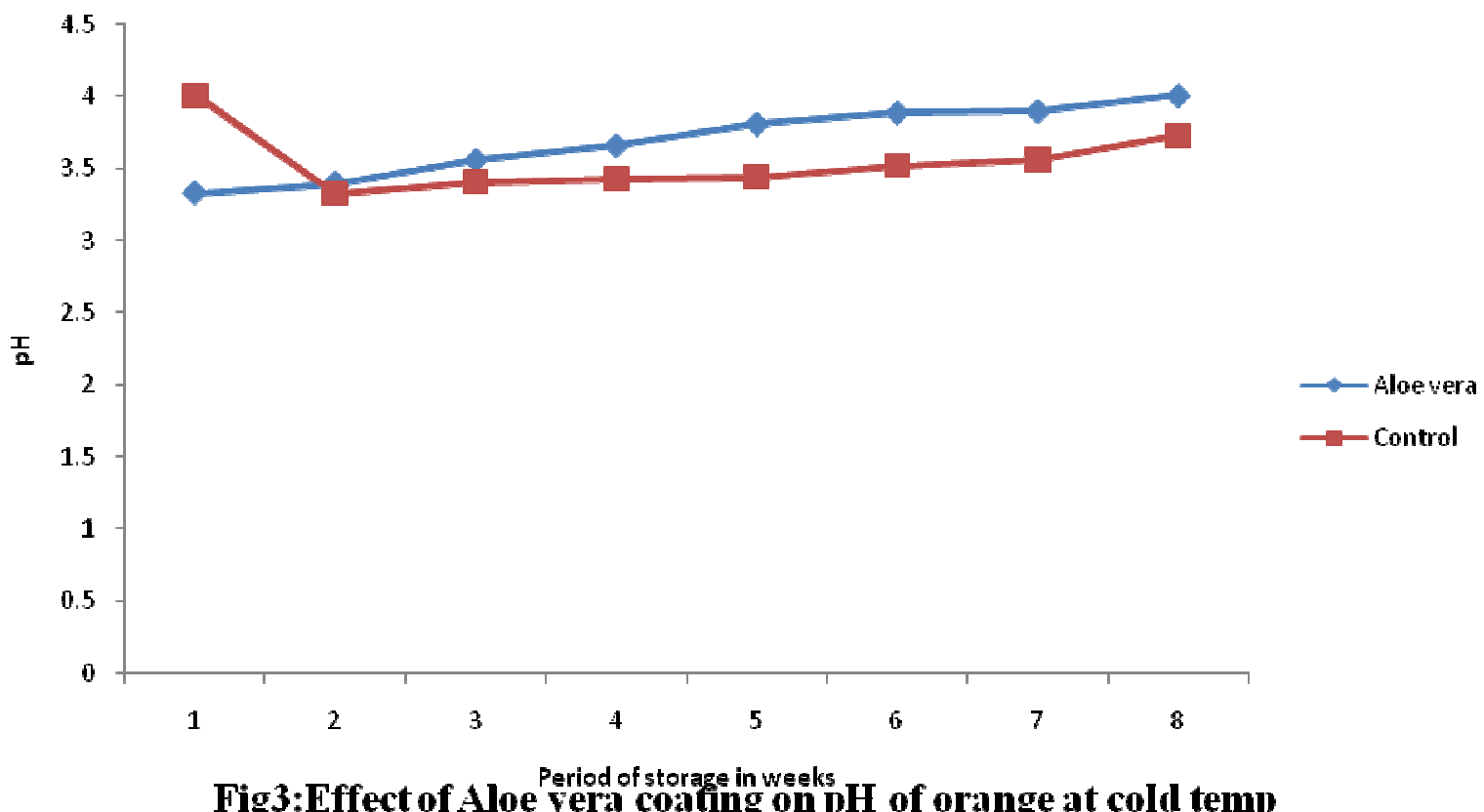


The $\mathrm{pH}$ of the orange juice was found to be gradually increasing during the course of storage as shown in Figure 3. The final value of $\mathrm{pH}$ for uncoated oranges was $3.53 \pm 0.17$, while that of coated oranges was $3.69 \pm 0.2$. There was no significant difference $(P>0.05)$ between the two treatments. It was found that coated oranges had higher value at the end of storage period, this was due to the semi-permeability created by aloe vera coatings on the surface of the fruit, which might have modified the internal atmosphere i.e. endogenous $\mathrm{O}_{2}$ and $\mathrm{CO}_{2}$ concentrations in the fruit, thus retarding ripening ( Lowings and cutts, 1982; Bai et al., 1988).

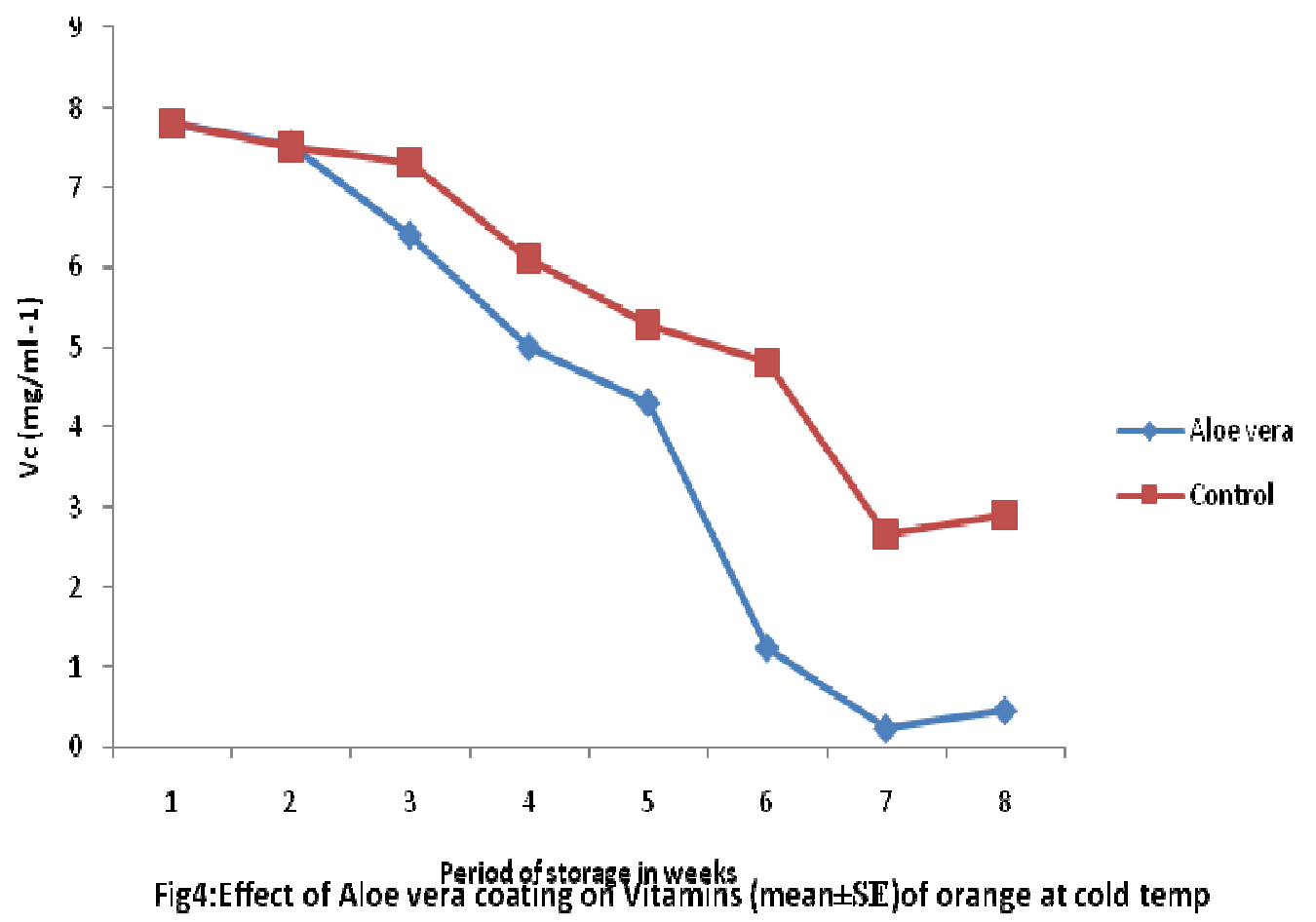

Figure 4 shows the effect of coating on vitamin C. Ascorbic acid is an important nutrient quality parameter that ascorbic acid content decreased with increasing period of storage in fruits of kinnow. Our findings were also in agreement with the work carried out by Bhattacharya (2004), who found that ascorbic acid of (Veltman (Veltman et. al., 2000) compared to other nutrient during food processing and storage. The value of vitamin $\mathrm{C}$ for coated oranges was found to be higher than that of uncoated i.e. control. The results of this study were in fresh fruit was maximum just before ripening and then decrease due to the action of enzyme called ascorbic acid oxidase. 


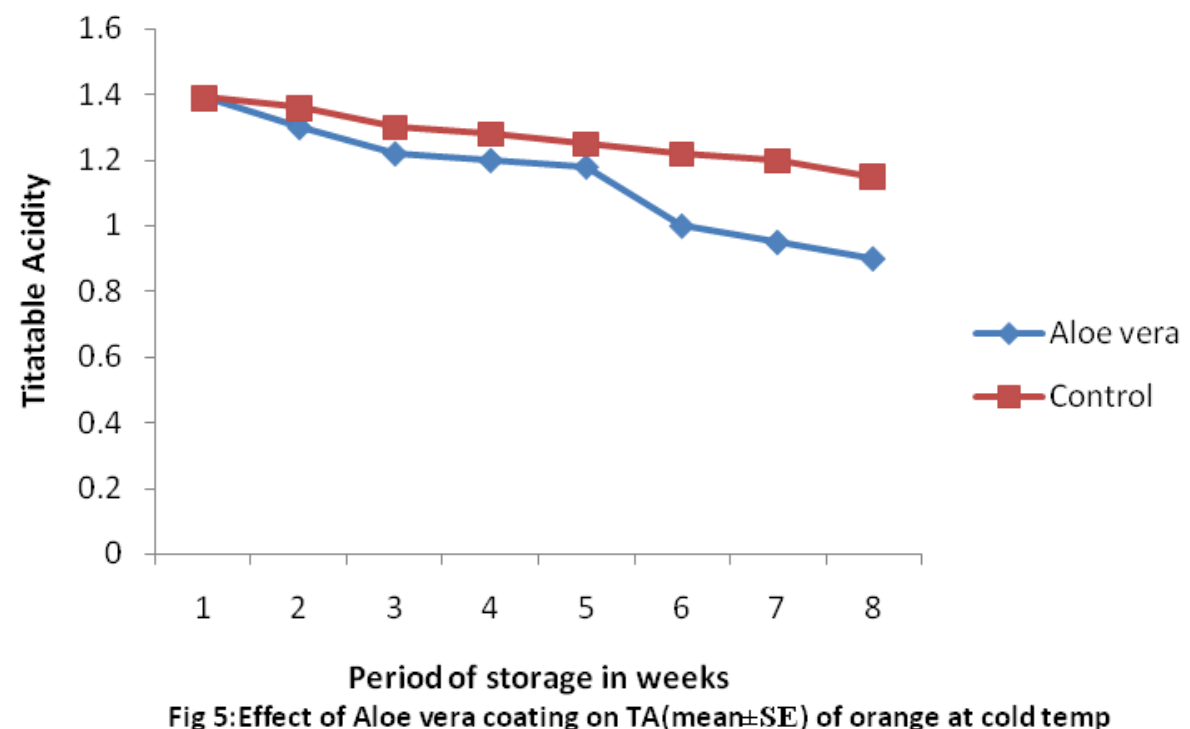

Figure 5 shows the effects of Aloe vera coatings on titratable acidity (TTA) during the course of cold storage. (TTA) is directly related to the concentration of organic acids present in the fruits. No significant difference ( $p>0.05$ ) was found in titratable acidity of coated and uncoated oranges. The final value of TTA of uncoated oranges at the end of storage was found to be $1.14 \pm$ $0.06 \%$, while that of coated oranges was $1.27 \pm 0.03 \%$. The decreasing acidity at the end of storage might be due to the metabolic changes in fruits resulting from the use of organic acids in respiratory process; this observation was in agreement with the findings of Echeverria and Valich (1989). Weight loss is an important index of Postharvest activities. It is mainly attributed to the loss of water during metabolic processes like respiration and transpiration. Moisture loss and gaseous exchange from the fruits are usually controlled by the epidermal provided by guard cells and stomata. The coating helps to reduce this further because it forms a film on the top of the skin acting as an additional barrier to moisture loss. This barrier also reduce oxygen uptake by the fruit which in turn slowed down rate of respiration and associated weight loss from the fruit surface. The mean value for the weight loss of coated oranges was $29.20 \pm 0.55 \%$ while that of uncoated oranges

was

$53.30 \pm 1.17 \%$.

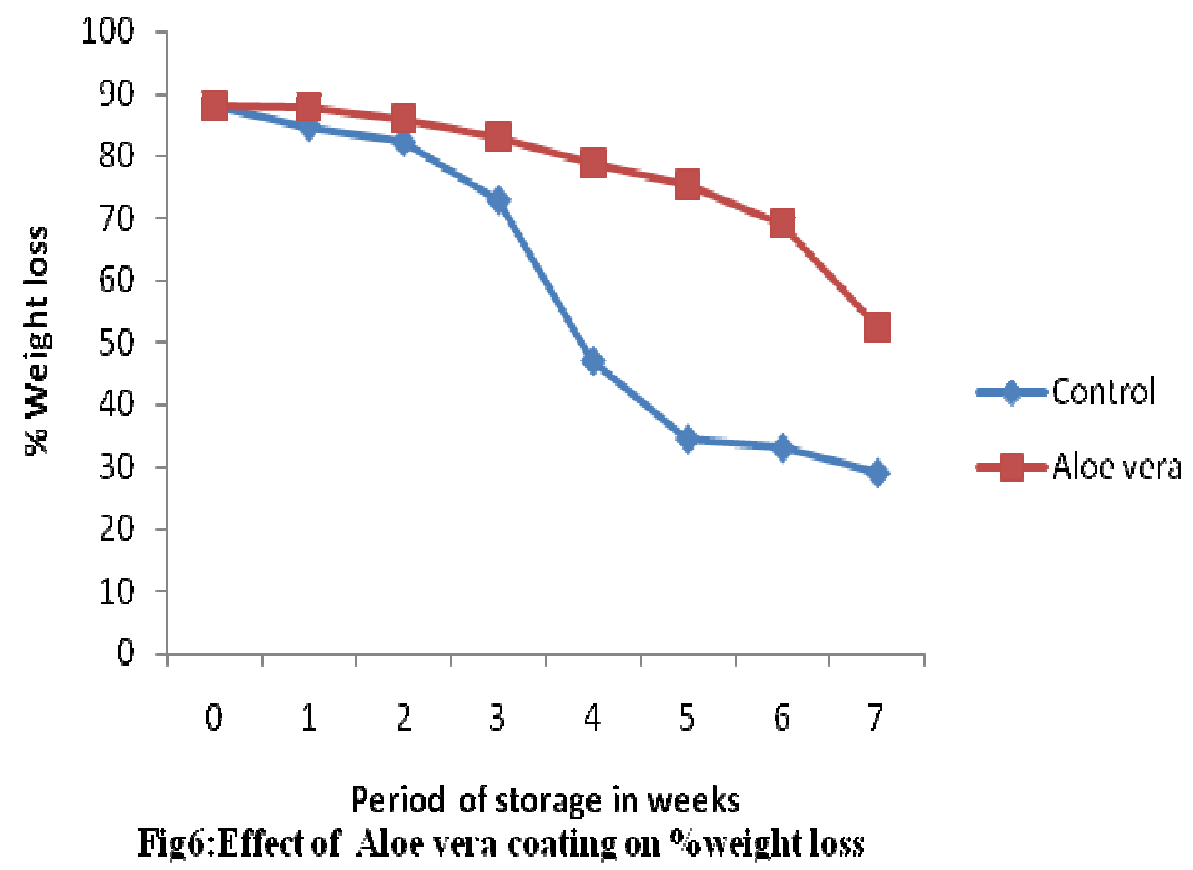


Figure 6 shows the effects of coatings on weight loss of oranges during the course of storage. The reduction in weight loss for coated oranges was probably due to the effects of these coatings as a semi-permeable barrier against oxygen, carbon-dioxide, moisture and solute movement, thereby reducing respiration, water loss and oxidation reaction rates (Baldwin et al., 1999; Park, 1999). The results obtained in this study are in agreement with the findings of Garc Aia et al., (1998 $a, b)$ for strawberries coated with starch- based coatings and those of Joyce et al.(1995) who reported that waxing extended the storage life of avocado both through reduction in water loss and modification of the internal atmosphere. Similar results were obtained by Bai et al. (2003) who studied Galla apple coated with $10 \%$ zein (natural corn protein). The sugar-acid ratio contributes to the unique flavor of citrus. At the beginning of the ripening process, the sugar- acid ratio is low because of low sugar content and high fruit acid content, this makes the fruit taste sour. During the ripening process the fruit acids are degraded, the sugar content increases, and the sugar- acid ratio achieves a higher value. The increase in sugar-acid ratio level could be attributed mainly to breakdown of starch into water, soluble sugars, sucrose and glucose during ripening.

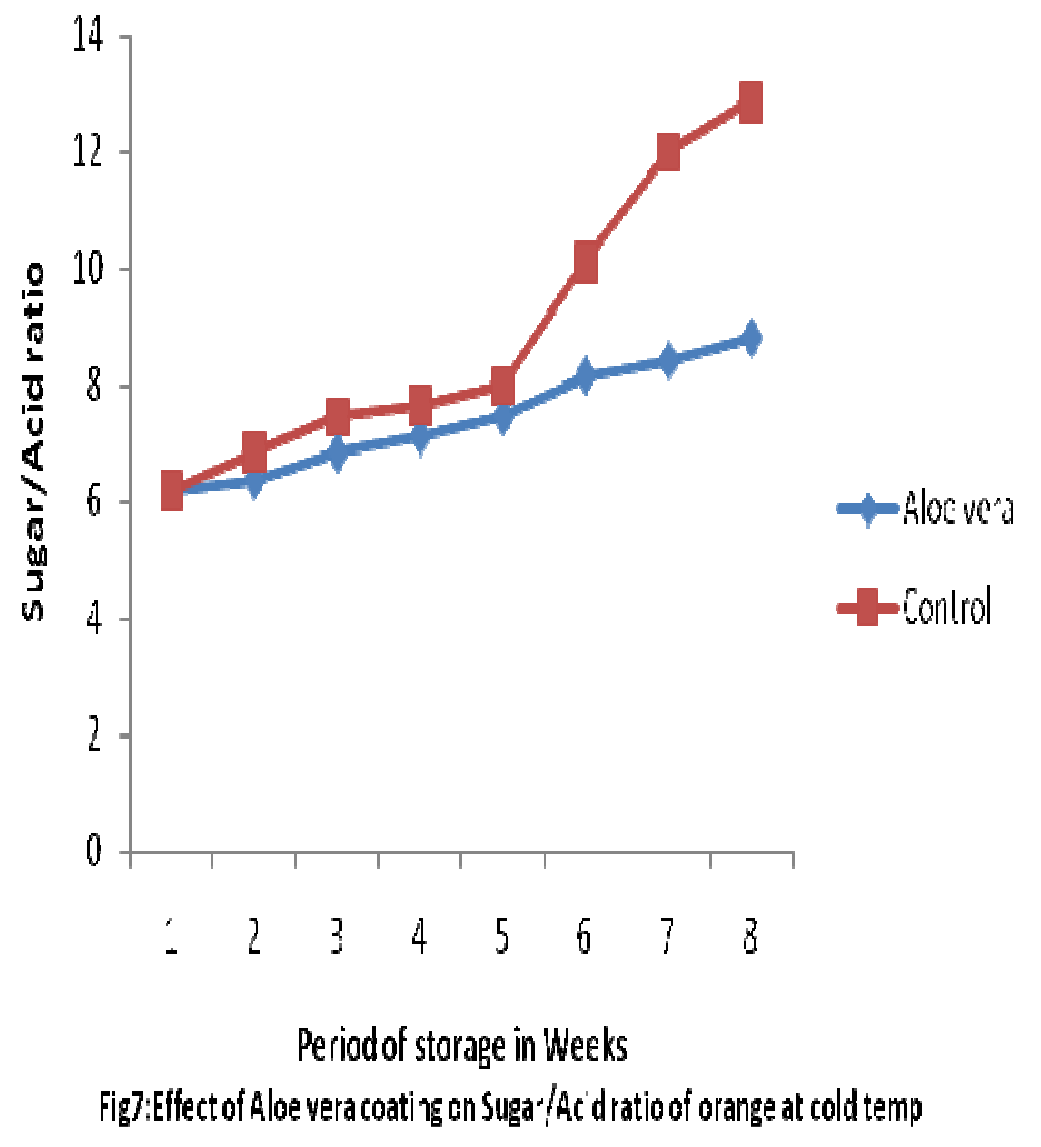

The final value for the sugar-acid ratio for coated orange was $7.43 \pm 0.34 \%$, while that of the uncoated oranges was $8.90 \pm 0.87 \%$ as shown in figure 7 . Significant differences $(\mathrm{P}<0.05)$ was observed in sugar- acid between oranges coated and the control during the course of storage. The finding in this study was similar to the work carried out by Manzano et al. (1997 a,b) who had similar decreasing trend in Hadden mango treated with wax coatings and stored at different temperatures.

\section{REFERENCES}

Aburjai, T.; Natsheh, F.M (2003). Plants used in cosmetics. Phytother. Res. 17, 987-1000.

Adetunji, C.O (2008). The antibacterial activities and preliminary phytochemical screening of vernonia amygdalina and Aloe vera against some selected bacteria. M.sc Thesis University of Ilorin. Pp.40-43.

Alleyne, V., Hagenmaier, R., (2000). Candelilla-shellac: an alternative formulation for coated apples. Hortscience 35, 691-693. 
Amarantee, C., Banks, N.H (2001). Post harvest physiology and quality of coated fruits and vegetables. Hort. Rev. 26, 161-238.

AOAC, (2000). Official methods of Analysis. Association of official Analytical chemists. 1111 North $19^{\text {th }}$ street, Suite 20, 17 th Edi. Arlington, Virginia, USA. 22209.

Bai, J., V. Alleyne, R.D. Hagemaier, J.P Mattheis and E.A. Baldwin, (2003). Formulation of zein coatings for Apples. (Malusdomestica borkh). Postharvest Biol. Technol., 28: 259-268.

Bai, R.K., Huang, M.Y and Jiang, Y.Y (1998). Selective permeabilities of chitosan-acetica acid complex membrane for oxygen and carbon dioxide. Polym. Bull. 20:83-88.

Bhattacharya, G. (2004). Served fresh spotlight. Time Food processing J. http://www.timesb2b.com/foodprocessing/dec03_jan 04/spotlight.html. Accessed: July 15, 2004.

Baldwin, E.A., J.K. Burns, W. Kazokas, J.K Brecht, R.D. Hagenmaier, R.J. Bender and E. Pesis, (1999). Effect of two edible coatings on mango (Mangifera indica L.) ripening during storage. Postharvest Biol. Technol., 17: 215-226.

Debeaufort, F. Quezada-Gallo, J.A. and Voilley, A. (1998). Edible films and coatings: tommorrow's packaging: a review. Crit. Rev. Food Sci. 38, 299313.

Echeverria, E. and Valich, J. (1989). Enzymes of sugar and acid metabolism in stored Valencia oranges. J. Am. Soc. Hort. Sci., 114:445-449.

Eshun, K. and He, Q. (2004) .Aloe Vera: a valuable ingredient for the food, pharmaceutical and cosmetic industries: a review. Crit.Rev. Food. Sci. Nutr. 44, 91-96.

Hagenmaier, R.D. and Baker, R.A. (1995). Layers of coatings to control weight loss and preserve gloss of citrus fruit. Hortscience 30, 296-298.

He, Q. J, Changhong, L.J, Kojo, E.J., Tian, Z, (2005). Quality and safety assurance in the processing of Aloe vera gel juice. Food control, 16, 95-104.

Jasso de Rodiguez, D.J Herna'ndez-castillo, D.J., Rodriguez Garcia, R., Angulo-sa'nchez. J.L. (2005). Antifungal activity in vitro of Aloe Vera pulp and liquid fraction against plant pathogenic fungi ind. Crop prod., 21, 81-87.

Garcia, M.A., M.N Martino and N.E. Zaritzky, (1998). Plasticized starch-based coatings to improve strawberry (Fragaria Ananassa) quality and storability. J. Agric. Food Chem., 46: 3758-3767.

Garcia, M.A., M.N Martino and N.E. Zaritzky (1998). Starch-based coatings: Effect on refrigerated strawberry (Fragaria ananassa) quality. J.Sci. Food Agric., 76: 411-420.

Jeong J., Huber, D.J and Sargent, S.A., (2003). Delay of avocado (Persea Americana). Fruit ripening by 1methyl cyclopentane and wax treatments, post harvest Biol. Techno. 28, 247-257.

Joyce, D.C., A.J Shorter and P.N Jones, (1995). Effect of delayed film wrapping and waxing on the shelf-life of avocado fruit. Aust. J. Exp. Agric., 35: 657-659.
Kittur, F.S., N. Saroja, Habibunnisa and R.N Tharanathan, (2001). Polysaccharide-based composite coating formulations for shelf life extension of fresh banana and mango. Eur. Food Res. Technol., 213: 306-311.

Kumar, J., R.K Sharma and R. Singh. (2000). The effect of different methods of packing on the shelf life of Kinnow. Haryana J. Horti. Sci. 29 (3-4) : 202-203.

Lowings, P.H and Cutts, D.F (1982). The preservation of fresh fruits and vegetables. In:Proc. Inst. Food Sci. Technol., Annual Symposium, Nottingham, UK.

Manzano, J.E., Y. Perez, and E. Rojas, (1997a). Coating waxes on Haden mango fruits (Mangifera indica L.) cultivar for export. Acta Hort., 455: 738-746.

Manzano, J.E., Y. Perez, E. Rojas, U. Lavi, C. Degani, S. Gwzit, E.Lahar and E. Pesis (1997b). Coating waxes on Haden mango fruit (Mangifera indica L.) cultivar for export. Proceedings of the fifth international mango symposium (Tel Aviv, Isreal, 1996), pp: 1-6.

Martinez-Romero D, Serrano M, Valera D and Castillo, S. (2003). Application de Aloe vera comorecubrinicetnto stobre frutas Yhor taliza, Spain patent-200302937.

Moore, E.D. and Mac Analley, B.H (1995). A drink containing mucilaginous polysaccharides and its preparation. U.S Patent 5, 443-530.

Morton, J. (1987). Fruits of warm climates. Published by Julia F. Morton 20534 SW 92 ct. Miami, FL. 33189. ISBN: 0-9610184-1-0, pp 50-58.

Ni, Y., Turner, D.; Yates, K. M.; Tizard, I. (2004). Isolation characterization of structural components of Aloe vera L. leaf pulp Int. Immunopharmacol. 4, $1745-1755$.

Park, H.J., (1999). Development of advanced edible coatings for fruits. Trends Food sci. Technol., 10: 250-260.

Patricia, S. T. Palmu, C.O. and C.R.F Grosso, (2005). Effect of edible wheat gluten-based films and coatings on refrigerated strawberry (Fragaria ananassa) quality postharvest Biol. Tecnol., 36:199208.

Reynolds, T. and Dwee, A.C. (1992). Aloe vera leaf gel: a review update. J. Ethnopharmacol. 68, 3-37.

Saks, Y and Barkai-Golan, R (1995). Aloe vera gel activity against plant pathogenic fungi, post harvest Biol. Technol 6: 159-165.

Salunkhe, D.K., H.R. Boun and N.R. Reddy (1991). Storage processing and Nutritional quality of fruits and vegetables. Vol. $1 \mathrm{CRC}$ press Inc., Boston.

Valuerde J.M., Valero A, Martinez-Romero D, Guileen F. and Castillo S. (2005). Novel edible coating based on Aloe vera gel to maintain table grape quality and safety, J. Agric. Food Chem 53, 7807-7813.

Vargas, M., Pastov, C., Chirau, A., Clements, M.C., Julian, D. and Gunzales, M. C. (2008). Recently advances in edible coatings for fresh and minimally processed fruits, Crit. Rev. Food Sci. Nutr. 48. 496511. 
Veltman, R.H., R.M Kho, A.C.R van Schaik, M.G Sanders and J. Oosterhaven. (2000). Ascorbic acid and tissue browning in pears (Pyrus communis L. cvs Rocha and conference) under controlled atmosphere conditions. Postharvest Biology and Technology 19(2), 129-137.
Yaman, O. and L. Bayoindirli, (2002). Effects of an edible coating and cold storage on shelf-life and quality of Cherries. Lebensm. Wiss. Und. Technol., 146-150.

Cite this Article: Arowora, KA, Williams JO, Adetunji CO, Fawole OB, Afolayan SS, Olaleye OO, Adetunji JB, Ogundele BA (2013). Effects of Aloe Vera Coatings on Quality Characteristics of Oranges Stored Under Cold Storage. Greener Journal of Agricultural Sciences, 3(1): 039-047, http://doi.org/10.15580/GJAS.2013.1.110112192. 